\title{
Recurrent EBV-Positive Diffuse Large B- Cell Lymphoma, Not Otherwise Specified
}

National Cancer Institute

\section{Source}

National Cancer Institute. Recurrent EBV-Positive Diffuse Large B-Cell Lymphoma, Not

Otherwise Specified. NCI Thesaurus. Code C153331.

The reemergence of EBV-positive diffuse large B-cell lymphoma, not otherwise specified after a period of remission. 